\title{
Short-Duration Grazing: The Facts in 1999
}

\author{
Jerry L. Holechek, Hilton Gomes, Francisco Molinar, Dee Galt, and Raul Valdez
}

$\mathrm{S}$ hort-duration grazing (also called rapid-rotation, timecontrolled, Savory grazing, holistic resource management) was conceived in Zimbabwe by Allan Savory in the 1960's and later introduced into the United States by Goodloe (1969). When Savory came to the United States in the late 1970's, he made further refinements discussed by Savory (1978), Savory and Parsons (1980), Savory (1983), and Savory (1988). During the 1980's short-duration grazing attracted much attention based on the claims it would accelerate range improvement while at the same time accommodating higher stocking rates. On many ranches it was contended that stocking rates could be doubled or even tripled while at the same time improving both range and livestock productivity.

Common conception of Savory grazing typically involves a wagon-wheel arrangement of fences with water and livestock handling facilities located in the center of the grazing area. However, it can be applied without the wagon-wheel design. A key feature is that a single herd of livestock is rotated through no fewer than 8 pastures (paddocks). Typically, the grazing period during active forage growth should be 5 days or less followed by 4 or more weeks of nonuse. It is recommended that livestock be moved more quickly during periods of active forage growth than in dormancy.

According to Savory and Parsons (1980), Savory (1983), and Savory (1988), short-duration or time-controlled grazing can do the following if properly implemented:

1. Improve water infiltration into the soil as a result of hoof action.

2. Increase mineral cycling.

3 . Reduce the percentage of ungrazed plants.

4. Improve livestock distribution (more uniform use of range).

5. Increase the period when actively growing forage is available to livestock.

6. Accelerate plant succession.
Savory's ideas generated much controversy among the range science academic community. Later Savory (1983) emphasized that holistic resource management (his grazing management approach) is not the same as short-duration grazing. He expressed doubt that holistic resource management could be validated experimentally because of its flexibility in animal numbers, length of grazing periods, number and arrangement of pastures, and various other management factors. Nevertheless, researchers at 13 locations in North America have attempted to evaluate the validity of Savory's ideas. They have generally been careful to use the term short-duration grazing rather than Savory grazing method or holistic resource management in describing the particular rotation scheme they evaluated. Still, they generally have related their findings to Savory's ideas and theories.

We will summarize present knowledge on short-duration grazing, focusing on a few recent studies that are fairly complete in terms of evaluating soil, vegetation, livestock, and financial responses over time and space. The managerial implications of these studies and their relevance to Savory's ideas will be given particular emphasis. Reviews of various grazing studies from Africa will be included in our discussion.

\section{Research Descriptions}

Most of the scientific information available on short-duration grazing is from prairie rangelands in the Great Plains or seeded dryland pastures (Table 1). Considerable information is available on short term impacts (1-4 years) of short-duration grazing on soils, vegetation, and livestock. However, there are only 4 studies in North America that have evaluated longer term vegetation, livestock, and financial outcomes under short-duration grazing (Heitschmidt et al. 1990, Taylor

Table 1. Primary studies evaluating short-duration grazing in North America.

\begin{tabular}{|c|c|c|c|c|}
\hline Rangeland Type & Location & $\begin{array}{l}\text { Livestock } \\
\text { Type Studies }\end{array}$ & $\begin{array}{l}\text { Duration } \\
\text { of study }\end{array}$ & $\begin{array}{l}\text { Primary } \\
\text { References }\end{array}$ \\
\hline & & & (years) & \\
\hline Crested wheatgrass & Oregon & Yearling cattle & 2 & Daugherty et. al 1982 \\
\hline Smooth bronze grass & Nebraska & Yearling cattle & 2 & Jung et al. 1985 \\
\hline Northern mixed prairie & North Dakota & Cow-Calf & 2 & Kirby et al. 1986 \\
\hline Crested wheatgrass & Utah & Yearling cattle & 3 & Olson and Malechek 1988 \\
\hline Chihuahuan desert & New Mexico & Cow-yearling & 2 & Anderson 1988 \\
\hline Southern mixed prairie & Texas & Yearling Cattle & 4 & Bryant et al. 1989 \\
\hline Northern mixed prairie & Alberta & Cow-cal & 5 & Willms et al. 1990 \\
\hline Southern mixed prairie & Texas & Cow-calf & 6 & Heitschmidt et al. 1990 \\
\hline Shortgrass & New Mexico & Cow-calf & 5 & White et al. 1991 \\
\hline Southern mixed prairie & Texas & Cattle-Sheep & 8 & Taylor et al. 1993 \\
\hline Crested wheatgrass & Oregon & Yearling cattle & 4 & Angell 1997 \\
\hline Shortgrass & Wyoming & Yearling cattle & 13 & Manley et al. 1997 \\
\hline Tallgrass prairie & Oklahoma & Yearling cattle & 6 & McCollum et al. 1999 \\
\hline
\end{tabular}


et al. 1993, Manley et al. 1997, McCollum et al. 1999). Generally, we consider these long term studies to be well designed and implemented.

\section{Hoof Action and Soils}

The best researched of Savory's claims is that short-duration grazing will increase water infiltration into the soil compared to continuous grazing. Several studies at different locations have been quite consistent in showing that hoof action from having a large number of animals on a small area for short time periods reduced rather than increased infiltration (McCalla et al. 1984, Thurow et al. 1986, Weltz and Wood 1986, Warren et al. 1986, Pluhar et al. 1987). These same studies have also been consistent in showing short-duration grazing increased erosion compared to continuous or seasonlong grazing. In the Warren et al. (1986) study, simulated short-duration grazing applied at progressively increased stocking rates progressively reduced infiltration and increased erosion compared to an ungrazed control (Table 2).

Table 2. Infiltration rate and sediment production in relation to stocking rate and soil water content at the time of trampling on the Edwards Plateau, Texas.

\begin{tabular}{lcc}
\hline \hline Stocking Rate & Trampled Dry & Trampled Moist \\
\hline Infiltration Rate $\left(\mathrm{mm} \mathrm{hr}^{-1}\right)$ & 166 & 160 \\
0 & 140 & 133 \\
$1 \mathrm{x}$ & 121 & 99 \\
$2 \mathrm{x}$ & 117 & 96 \\
$3 \mathrm{x}$ & & \\
& & \\
Sediment production $\left(\mathrm{Kg} \mathrm{ha}^{-1}\right)$ & 976 & 2,007 \\
0 & 2,827 & 2,875 \\
$1 \mathrm{x}$ & 3,438 & 4,274 \\
$2 \mathrm{x}$ & 4,788 & 5,861 \\
$3 \mathrm{x}$ & &
\end{tabular}

Source: Warren et al. 1986.

$1 \mathrm{x}=$ moderate stocking rate, $2 \mathrm{x}=$ twice moderate stocking rate, $3 \mathrm{x}=$ triple moderate stocking rate.

In our search of the literature we could find no studies that substantiate Savory's claims on the benefits of hoof action on range soils. One of the most intensive studies of short-duration grazing impacts on range soils was conducted in Alberta, Canada over a 5 year period (Dormaar et al. 1989). In this study, short-duration grazing at twice or triple the recommended rate reduced soil moisture, increased soil bulk density, and reduced fungus biomass compared to an ungrazed exclosure. Hoof action did not significantly increase incorporation of litter into the soil. The hypothesis that controlled animal impact as recommended by Savory would improve soil health was rejected. Another study, conducted at 3 sites in Alberta, showed time controlled (short-duration) grazing reduced soil organic matter and nitrogen but increased phosphorus over ungrazed controls (Willms et al. 1990). It was concluded that using high animal density and stocking rates with time-controlled grazing would result in range deterioration.

\section{Forage Production}

Several studies now show that there is little difference in forage production between short-duration and continuous grazing systems if stocking rates are the same (Jung et al. 1985, Pitts and Bryant 1987, Anderson 1988, Thurow et al. 1988, White et al. 1991, Manley et al. 1997). In a 6 year study on blue grama rangeland in south-central New Mexico, total grass production averaged $828 \mathrm{lbs}^{\mathrm{bcre}} \mathrm{ander}^{-1}$ continuous grazing compared to $724 \mathrm{lbs}$ acre ${ }^{-i}$ under short-duration grazing. In north-central Texas, Heitschmidt et al. (1990) reported forage production averaged $2,300 \mathrm{lbs}$ acre $\mathrm{e}^{-1}$ for heavy continuous, 2,500 lbs acre ${ }^{-1}$ for moderate continuous, $2,700 \mathrm{lbs}^{\mathrm{bcre}}{ }^{-1}$ for Merrill $3 \mathrm{herd} / 4$ pasture, and 2,600 lbs acre ${ }^{-1}$ for short-duration grazing. Only the heavy continuously grazed treatment differed significantly from the others. In the tall grass prairie of Oklahoma, standing crop of forage averaged $16 \%$ higher under short-duration compared to continuous grazing $(3,200$ vs. 2,760 lbs acre-1) (Cassels et al. 1995). However, it was later reported that this was not due to greater plant vigor under short-duration grazing but rather higher forage intake by steers under continuous grazing (McCollum et al. 1999). In north-central Texas herbage growth dynamics did not differ between short-duration and continuous grazing (Heitschmidt et al. 1987b) or between 14 versus 42 paddock short-duration grazing (Heitschmidt et al. 1987a).

\section{Plant Succession and Range Condition}

Several studies have shown short-duration grazing to be similar to continuous grazing in effects on plant succession and range condition if stocking rates were the same (Pitts and Bryant 1987, White et al. 1991, Manley et al. 1997, Gillen et al. 1998). In a south Texas study, it was found that progressively increasing the stocking rate under short-duration grazing up 2.5 times the rate recommended by Merrill (1954) caused the frequency and composition of mid-grasses to decline but shortgrasses were not affected (Ralphs et al. 1990). Standing crop of all major forage classes declined as stocking rate increased under short-duration grazing. Another study at the same location (Sonora Research Station) showed short-duration grazing did not promote secondary succession from shortgrasses to mid-grasses as effectively as high intensitylow frequency grazing (Taylor et al. 1993).

The most complete study in North America on short-duration grazing in terms of replication in time and space was conducted on shortgrass prairie in southeastern Wyoming (Manley et al. 1997). They compared season-long, deferred rotation and short-duration grazing at 3 stocking rates. Over a 13 year period changes in bare ground and vegetation composition were primarily a function of stocking rate rather than grazing system. There were trends towards more bare ground and less western wheatgrass as stocking rate increased. During this study, deferred rotation, time-controlled (short-duration), and season-long grazing did not differ in their effects on either forage production or plant succession. In a 5 year New Mexico study, blue grama cover was slightly higher but other grasses (primarily mid-grasses) were lower under short-duration compared to continuous grazing (White et al. 1991). It 
was concluded any differences in short-duration compared to continuous grazing in terms of plant productivity or succession were doubtful. In Alberta, Canada Willms et al. (1990) compared plant succession on time-controlled grazing and protected areas over a 6 year period. They used high stocking rates and high livestock densities. Utilization averaged about $80 \%$ of available forage over the study period. In this study time-controlled grazing caused a definite decline in range ecological condition on mixed prairie and rough fescue prairie sites. The hypothesis that time-controlled grazing with high stocking rates and high stock densities will improve rangeland condition was strongly rejected by the authors.

\section{Harvest Efficiency and Livestock Distribution}

Research does not support the Savory and Parsons (1980) contention that short-duration grazing will improve forage harvest efficiency (Kirby et al. 1986, Heitschmidt et al. 1987a, 1987b, Hart et al. 1989, Bryant et al. 1989, Walker et al. 1989). In North Dakota, Kirby et al. (1986) found that increased stocking rate and stock densities under short-duration grazing did not improve grazing distribution over season-long grazing. In Wyoming, Hart et al. (1989) found pasture subdivisions of equal sizes under short-duration and continuous grazing had the same utilization patterns. However, a large continuously grazed pasture was less uniformly used than small continuous and short-duration grazed pastures. It was concluded the benefit of short-duration grazing in terms of increasing grazing capacity was entirely from pasture subdivision rather than rotation of livestock.

\section{Livestock Productivity}

Findings on how short-duration grazing impacts livestock productivity show some inconsistency. Four studies have shown short-duration grazing has lowered individual livestock productivity compared to continuous or season-long grazing (Parker et al. 1987, Anderson 1988, Heitschmidt et al. 1990, McCollum et al. 1999). Another 5 studies showed no difference between short-duration and continuous grazing (Jung et al. 1985, Pitts and Bryant 1987, Olson and Malechek 1988, Taylor et al. 1993, Manley et al. 1997) while 1 study showed short-duration grazing increased livestock productivity (Daugherty et al. 1982). A careful analysis of these 10 studies indicates small or no difference in livestock productivity between short-duration and continuous grazing if stocking rates are equal with one exception. McCollum et al. (1999) found live weight gains of yearling cattle were 11 to $20 \%$ lower under short-duration than season long grazing when averaged across six levels of stocking. This was caused by lower forage intake of cattle under short-duration grazing (McCollum and Gillen 1998).

Forage and diet quality under short-duration and continuous/season-long grazing have generally shown little difference if stocking rates were comparable (Jung et al. 1985, Anderson 1988,Olson and Malechek 1988, Heitschmidt et al. 1987b). One exception is Hirschfield et al. (1996) who found both cattle diet crude protein content and forage intake to be increased by short-duration grazing on mixed prairie rangeland in North Dakota. They attributed this to more growth opportunity through periodic rest under short-duration grazing. In contrast, McCollum and Gillen (1998) found diet quality and forage intake of steers were lower under short-duration than continuous grazing on tall grass prairie in Oklahoma.

\section{Financial Returns}

Limited research indicates that short-duration grazing has no financial advantage over continuous/season long grazing (Table 3). Lower individual animal productivity under shortduration grazing is the primary explanation why it gave inferior net returns compared to season-long grazing in south-central Oklahoma (McCollum et al. 1999).

Holechek (1992) discussed potential financial returns from a medium sized (250 animal unit) cow-calf operation under short-duration grazing in the Chihuahuan Desert of New Mexico. He modeled a best case scenario that assumed stocking rate could be increased $50 \%$ over recommended rates with no adverse impact on forage production, no decline in cattle productivity, no increase in fixed costs, and no interest rate cost would be incurred for capital investment. He used average cattle price and ranching costs for the 1986-1991 period. Total cost for the short-duration grazing program was $\$ 190,400$. He found best case return on investment from short-duration grazing was $8.1 \%$, which was nearly the same as 30 year U.S. treasury bonds and below the historic return of the U.S. stock market $(10 \%)$. Extended drought and lower cattle prices have occurred in the Chihuahuan Desert since 1992. The hypothetical short-duration operation Holechek (1992) discussed could easily have lost $\$ 48,000$ or $25 \%$ of its investment due to forced cattle liquidation at prices well below those in the 1986-1991 period. Further reductions in returns from the above short-duration grazing scenario are probable. Parker et al. (1987), in south-central New Mexico, found short-duration grazing at a stocking rate $25 \%$ above that for

Table 3. Financial returns from studies comparing short-duration and continuous grazing systems.

\begin{tabular}{|c|c|c|c|c|}
\hline \multirow[b]{2}{*}{ Study } & \multirow[b]{2}{*}{ Location } & \multirow[b]{2}{*}{$\begin{array}{l}\text { Type of } \\
\text { Livestock }\end{array}$} & \multicolumn{2}{|c|}{ Net Returns } \\
\hline & & & $\begin{array}{l}\text { Short-Duration } \\
\text { grazing }\end{array}$ & $\begin{array}{c}\text { Continuous } \\
\text { grazing }\end{array}$ \\
\hline & & & \multicolumn{2}{|c|}{ (\$/acre) } \\
\hline Heitschmidt et al. 1990 & North-central Texas & Cow-calf & 6.36 & 5.25 \\
\hline Taylor et al. 1993 & South-central Texas & Cattle-sheep & 7.39 & 7.20 \\
\hline Manley et al. 1997 & South-eastern Wyoming & Yearling cattle & 12.07 & 15.20 \\
\hline McCollum et al. 1999 & North-central Oklahoma & Yearling cattle & 2.83 & 8.50 \\
\hline Average across studies & & & 7.16 & 9.04 \\
\hline
\end{tabular}


moderate continuous grazing lowered calf crops about $14 \%$ compared to moderate continuous grazing. Calf weaning weights were also depressed under short-duration grazing.

\section{Studies from Africa}

Two comprehensive reviews are available that consider African experiences with short-duration grazing (Skovlin 1987, O'Reagain and Turner 1992). Over 50 grazing experiments are evaluated by these reviews. Authors of both reviews drew essentially the same conclusions that are as follows:

1. Stocking rate has a major impact on range condition and animal production.

2. Continuous and short-duration grazing systems differ little in their effects upon range condition and livestock production.

3. Multi-camp ( 8 or more paddocks) rotation systems have no advantage over 4 paddock systems in either vegetation or livestock productivity.

4. Continuous grazing at moderate stocking rates does not cause rangeland degradation.

5. Herd effects from grouping large numbers of animals together lower water infiltration and increase erosion.

6. Grazing intensity rather than rotation system is the primary factor determining long term grazing outcomes on vegetation, livestock, and financial returns.

North American grazing studies strongly support these conclusions (Holechek et al. 1999).

\section{Some Analysis and Conclusions}

We find it interesting that government agencies so readily accepted Savory's theories and aggressively encouraged use of short-duration grazing. Grazing research that was available by the late 1970 's already refuted much of what Savory contended but it received little consideration by many ranchers and government employed range managers. History shows that it's human nature to believe a good story rather than pursue the truth. Many ranchers undoubtedly found the prospect of much higher profits through use of Savory grazing methods most appealing. However, scientific investigation has disproven many of the early claims for short-duration grazing. This is particularly true regarding hoof action and accelerated range improvement from increased stocking rates and densities.

What led to such a widespread acceptance of the high intensity grazing concept without scientific proof? Initial programs in the early 1980's came at the end of a period of low cattle prices and low precipitation. From the middle 1980's through the early 1990's both cattle prices and rainfall drastically increased. Precipitation for the 1984-1993 period was $27 \%$ above the long term average across New Mexico (Holechek 1996). This more than doubled forage production. Wondrous tales were told regarding the effects of short-duration grazing on vegetation and livestock productivity. However, nature also taketh away. From 1993 to the present drought has prevailed across northern Mexico, Texas, and New Mexico. The hard lessons learned in Africa about short-duration grazing and drought in the early 1980's (Gammon 1984) are now being learned by many southwestern USA/Mexican ranchers
(Holechek 1996, Molinar et al. 1998). No grazing approach, including that of Savory, will overcome the adverse effects of drought and/or chronic heavy stocking on forage production (Pieper and Heitschmidt 1988). Conservative stocking has been scientifically proven to be the surest grazing approach to maximizing plant productivity under drought, and improving rangeland condition (Klipple and Costello 1960, Paulsen and Ares 1962, Martin and Cable 1974, Holechek et al. 1994).

It is our view that the U.S. and Mexican governments should never have aggressively spent money on training range personnel on unproven theories or provided cost sharing for implementation of short-duration grazing until it had been fully evaluated. We can only wonder what the outcome might have been if government agencies had spent this money on educating their personnel and ranchers on scientifically proven range management practices and principles. We agree with O'Reagain and Turner (1992) who stated range managers should adopt a more critical attitude so as to prevent the assimilation of untested hypotheses into accepted management practices.

Ranchers across the southwestern USA and Mexico have suffered severe financial losses since 1994 (Holechek 1996, Molinar et al. 1998, Torell et al. 1998). Part of their problem centers around using high risk management strategies involving heavy stocking rates (Molinar et al. 1998, Ward 1998, Ward 1999). This may also have intensified rancher/environmentalist conflicts as rangeland ecosystem sustainability depends heavily on maintaining adequate levels of standing vegetation biomass (Heitschmidt and Walker 1996).

Short-duration grazing can facilitate improved management of livestock, and it gives ranchers more control over how specific parts of their ranch are grazed than continuous grazing. We believe it can be a useful grazing system for some ranchers if applied at conservative to moderate stocking rates. In closing, we hope the scientific information we have identified in this article will be more widely read and lead to better informed decisions on the use of short-duration grazing. Controversy generated by Allan Savory has, without doubt, led to more thorough investigation of various grazing processes. This research should now be put into practical application.

\section{Supporting Literature}

Anderson, D. M. 1988. Seasonal stocking of tobosa managed under continuous and rotation grazing. J. Range Mange. 41:78-83.

Angell, R. F. 1997. Crested wheatgrass or shrub response to continuous or rotational grazing. J. Range Manage. 50:160-164.

Bryant, F. C., B. E. Dahl, R. D. Pettit, and C. M. Britton. 1989. Does short-duration grazing work in arid and semi-arid regions? J. Soil and Water Cons. 44:290-296.

Cassels, D. M., R. L. Gillen, F. Ted McCollum, Kenneth W. Tate, and Mark E. Hodges. 1995. Effects of grazing management on standing crop dynamics in tallgrass prairie. J. Range Manage. 48:81-84.

Daugherty, D. A., C. M. Britton, and H. A. Turner. 1982. Grazing management of crested wheatgrass for yearling steers. J. Range Manage. 35:347-350.

Dormaar, J. F., S. Smoliak, and W. D. Willms. 1989. Vegetation and soil responses to short-duration grazing on fescue grasslands. J. Range Manage. 42:252-256.

Gammon, D. M. 1984. An appraisal of short duration grazing as a method of veld management. Zimbabwe J. Agric. Res. 84:59-64.

Gillen, R. L., F. T. McCollum III, K. W. Tate, and M. E. Hodges. 
1998. Plant community response to grazing system and stocking rate in tallgrass prairie. J. Range Manage. 51:139-146.

Goodloe, S. 1969. Short-duration grazing in Rhodesia. J. Range Manage 22:369-373.

Hart, R. H., M. J. Samuel, J. W. Waggoner, Jr., and M. A. Smith. 1989. Comparisons of grazing systems in Wyoming. J. Soil and Water Cons. 44:344-347.

Heitschmidt, R. F. and J. W. Walker. 1996. Grazing management: technology for sustaining rangeland ecosystems. Rangelands. 18:194-215.

Heitschmidt, R. K., S. L. Dowhower, and J. W. Walker. 1987a. 14- vs 42-paddock rotational grazing: Aboveground biomass dynamics, forage production and harvest efficiency. J. Range Manage. 40:216-244.

Heitschmidt, R. K., S. L. Dowhoer, and J. W. Walker. 1987b. Some effects of a rotational grazing treatment on quantity and quality of available forage and amount of ground litter. J. Range Manage. 20:318-321.

Heitschmidt, R. K., J. R. Conner, S. K. Canon, W. E. Pinchak, J. W. Walker, and S. L. Dowhower. 1990. Cow/calf production and economic returns from year-long continuous deferred rotation and rotational grazing treatments. J. Prod. Agr. 3:92-99.

Hirschfield, D. J., D. R. Kirby, J. S. Caton, S. S. Silcox, and K. C. Olson. 1996. Influence of grazing management on intake and composition of cattle diets. J. Range Manage. 49:257-263.

Holechek, J. L. 1992. Financial benefits of range management practices in the Chihuahuan Desert. Rangelands 14:279-282.

Holechek J. L. 1996. Drought and low cattle prices: hardship for New Mexico ranchers. Rangelands 18:11-13.

Holechek, J. L., H. Gomez, F. Molinar, and D. Galt. 1999. Grazing studies: What we've learned. Rangelands 2l(2):12-16.

Holechek, J. L., A. Tembo, A. Daniel, M. Fusco, and M. Cardenas. 1994. Long term grazing influences on Chihuahuan Desert Rangeland. Southern Nat. 39:342-349.

Jung, H. G., R. W. Rice, and L. J. Koong. 1985. Comparison of heifer weight gains and forage quality for continuous and short-duration grazing systems. J. Range Manage. 38:144-149.

Kirby, D. R., M. F. Pessin, and G. K. Clambrey. 1986. Disappearance of forage under short-duration and season-long grazing. J. Range Manage. 39:496-499.

Klipple, G. E. and D. F. Costello. 1960. Vegetation and cattle responses to different intensities of grazing on shortgrass ranges of the central Great Plains. U.S. Dept. Agr. Tech. Bull. 1216.

Manley, W. A., R. H. Hart, M. J. Samuel, M. A. Smith, J. W. Waggoner, Jr., and J. T. Manley. 1997. Vegetation, cattle and economic responses to grazing strategies and pressures. J. Range Manage. 50:638-646.

Martin, S. C. and D. R. Cable. 1974. Managing semidesert grass-shrub ranges: Vegetation responses to precipitation, grazing, soil texture, and mesquite control. U.S. Dept. Agr. Tech. Bull. 1480.

McCalla, G. R. II, W. H. Blackburn, and L. B. Merrill. 1984. Effects of livestock grazing on infiltration rates, Edwards Plateau of Texas. J. Range Manage. 37:265-269.

McCollum, F. T. III and R. L. Gillen. 1998. Grazing management affects nutrient intake by steers grazing tallgrass prairie. J. Range Manage. 51:69 72 .

McCollum, F. T. III, R. L. Gillen, B. R. Karges, and M. E. Hodges. 1999. Stocker cattle response to grazing management in tallgrass prairie. J. Range Manage. 52:120-126.

Merrill, L. B. 1954. A variation of deferred rotation grazing for use under southwest range conditions. J. Range Manage. 7:152-154.

Molinar, F., H. de Souza Gomes, J. L. Holechek, and R. Valdez. 1998. Mexico, macro-economics, and range management. Rangelands 20:16-24.

Olson, K. C. and J. C. Malechek. 1988. Heifer nutrition and growth on short-duration grazed crested wheatgrass. J. Range Manage. 41:259-263.

O'Reagain, P. J. and J. R. Turner. 1992. A evaluation of the empirical basis for grazing management recommendations for rangeland in southern Africa. J. Grassl. Soc. Southern Africa 9:1-52.
Parker, E. E., G. B. Donart, R. D. Pieper, J. D. Wallace, and J. D. Wright. 1987. Response of range beef cattle to different grazing management systems. New Mexico Agr. Expt. Sta. Bul. 732.

Paulsen, H. A. and F. N. Ares. 1962. Grazing values and management of black grama and tobosa grasslands and associated shrub ranges of the southwest. U.S. Dept. Agr. Tech. Bull. 1270.

Pieper, R. D. and R. K. Heitschmidt. 1988. Is short-duration grazing the answer. J. Soil and Water Cons. 43:133-137.

Pitts, J. S. and F. C. Bryant. 1987. Steer and vegetation response to shortduration and continuous grazing. J. Range. Manage. 40:386-389.

Pluhar, J. J., R. W. Knight, and R. K. Heitschmidt. 1987. Infiltration rates and sediment productions as influenced by grazing systems in the Texas Rolling plains. J. Range Manage. 40:240-244

Ralphs, M. H., M. M. Kothmann, and C. A. Taylor, Jr. 1990. Vegetation response to increased stocking rates in short-duration grazing. J. Range Manage. 43:104-108.

Savory, A. 1978. A holistic approach to range management using shortduration grazing. Proc. Intn'l. Rangel. Congr. 1:555-557.

Savory, A. 1983. The Savory grazing method or holistic resource management. Rangelands 5:155-159.

Savory, A. 1988. Holistic resource management. Island Press, Washington, DC.

Savory, A. and S. D. Parsons. 1980. The Savory grazing method. Rangelands 2:234-237.

Skovlin, J. M. 1987. Southern Africa's experience with intensive shortduration grazing. Rangelands 9:162-168.

Taylor, C. A. Jr., N. E. Garza Jr., and T. D. Brooks. 1993. Grazing systems on the Edwards Plateau of Texas: Are they worth the trouble? II. Rangelands 15:57-61.

Thurow, T. L., W. H. Blackburn, and C. A. Taylor Jr. 1986. Hydrologic characteristics of vegetation types as affected by livestock grazing systems, Edwards Plateau, Texas, J. Range Manage. 39:505-509.

Thurow, T. L., W. A. Blackburn, and C. A. Taylor, Jr. 1988. Some vegetation responses to selected livestock grazing strategies, Edwards Plateau, Texas. J. Range Manage. 41:108-114.

Torell, L. A., J. M. Hawkes, and T. D. Stromei. 1998. Range livestock cost and return estimates for New Mexico, 1996. New Mexico State Univ. Agr. Exp. Sta. Rep. 726.

Walker, J. W., R. K. Heitschmidt, and S. L. Dowhower. 1989. Some effects of a rotational grazing treatment on cattle preference for plant communities. J. Range Manage. 42:143-148.

Ward, N. 1998. Sustainable ranching: A ranchers perspective. Rangelands 20(3):33-37.

Ward, N. 1999. Ranchers need support for sustainable ranching: What government can do: A ranchers perspective. Rangelands 21(3): 13-17.

Warren, S. D., W. H. Blackburn, and C. A. Taylor, Jr. 1986. The influence of livestock trampling under intensive rotation grazing on soil hydrological condition. J. Range Manage. 39:491-496.

Weltz, M. and M. K. Wood. 1986. Short-duration grazing in central New Mexico: Effects on infiltration rates. J. Range Manage. 39:365-368.

White, M. R., R. D. Pieper, G. B. Donart, and L. White-Trifaro. 1991. Vegetation response to short-duration and continuous grazing in southcentral New Mexico. J. Range Manage. 44:399-404.

Willms, W. D., S. Smoliak, and J. F. Dormaar. 1990. Vegetation response to time-controlled grazing on mixed and fescue prairie. J. Range Manage. 43:513-518.

The authors are professor and adjunct professor of range science, Department of Animal and Range Sciences, New Mexico State University, Las Cruces, New Mexico 88003; assistant professor of range science, University of Juarez, Juarez, Mexico; private range consultant, Las Cruces, New Mexico 88005; and professor of wildlife science, Department of Fisheries and Wildlife science, New Mexico State University, Las Cruces, New Mexico, 88003. This paper was supported by the New Mexico Agricultural Experiment Station and was part of project 1-5-27417. 